\title{
Bluetongue disease in sheep: a review
}

\section{O vírus da língua azul em ovinos: uma revisão}

\section{Luiz Fernando Coelho da Cunha Filho ${ }^{1 *}$ (D), Maria Carolina Ricciardi Sbizera² (D, José Victor Pronievicz Barreto' ${ }^{1}$ (D), Edwiges Maristela Pituco ${ }^{3}$ (D), Elis Lorenzetti ${ }^{2}$ (D), Michele Lunardi ${ }^{4}$, Thais Helena Constantino Patelli' ${ }^{1}$, Bruna Fonseca Matias ${ }^{2}$}

\begin{abstract}
The present review aims to show the main aspects related to bluetongue virus (BTV) infection in sheep. The bluetongue (BT) is a viral, infectious, and non-contagious disease caused by a virus (BTV) of the Orbivirus genus, transmited by a hematophagous vector of the Culicoides genus, to domestic and wild ruminants, mainly to sheep, the most susceptible species. It is caused by the association of endemic with climate conditions, with high temperatures and humidity. Economic loss is directly linked to death, abortion, weight loss, loss of milk, and meat production, and, indirectly, to the restriction on the export of animals and their by-products. The study concludes that the BTV is worldwidely spread, and probably persists due to the warm and humid climate that leads to the proliferation of Culicoides sp., being necessary to adopt measures that reduce the risk factors associated to the BTV infection.
\end{abstract}

KEYWORDS: Culicoides; Orbivirus; AGID; ELISAc.
RESUMO: A presente revisão objetivou apresentar os principais aspectos relacionados à infecção causada pelo vírus da língua azul em ovinos. A língua azul é uma doença viral, infecciosa e não contagiosa, causada por um vírus (BTV) do gênero Orbivírus, transmitida por meio de vetores hematófagos do gênero Culicoides a ruminantes domésticos e selvagens, principalmente aos ovinos, a espécie mais susceptível. A infecçâo ocorre de forma endêmica, associada a condiçôes climáticas com elevada temperatura e umidade. As perdas econômicas estão ligadas diretamente à morte, ao abortamento, à perda de peso, à perda na produçáo de leite e carne, e, indiretamente, devido à restrição na exportação de animais e seus subprodutos. $\mathrm{O}$ estudo conclui que a língua azul está disseminada mundialmente e persiste, provavelmente, devido ao clima quente e úmido que propicia a proliferaçáo de Culicoides sp., sendo necessário adotar medidas que diminuam os fatores de risco associados à infecção pelo vírus.

PALAVRAS-CHAVE: Culicoides; Orbivírus; IDGA; ELISAc. 


\section{INTRODUCTION}

Sheep farming was spread to practically all continents, due to the adaptive ability of the species to the different climatic conditions. In Brazil, trends for sheep production were proven highly feasible and promising, seen that the herd is growing greatly in recent years.

As to the important socioeconomic increase in the Brazilian sheep farming, the health security of the productive chain is fundamental. It is known that the occurence of virus is common in sheep, and loss due to this occurrence are common (SOUZA et al., 2010). Among these diseases, the bluetongue (BT), a compulsory disease (OIE, 2018) stands out, and economic impacts are associated to the decrease in production and increased mortality in animals (COSTA et al., 2006).

The economic loss due to this disease was not expressed in exact numbers, but the estimate is US $\$ 300$ million a year. However, there is little data about it in Brazil. Loss is both direct, such as death, abortions, weigh loss, or reduced milk yield and meat efficiency, and indirect, as a result of export restrictions for live animals and their by-products (TOMICH et al., 2009).

The BT, is an infectious and non-contagious disease, caused by the bluetongue virus (BTV). This virus is a member of the Orbivirus genus and is transmitted to the ruminants by biting midges of the Culicoides genus (NOAMAN; ARZANI, 2016).

Over the last ten years in Brazil, several sero-epidemiological studies demonstrated the presence of the virus in different regions (TOMICH et al., 2009; ALVES et al., 2009; NOGUEIRA et al., 2009; SOUZA et al., 2010; MOTA et al., 2011; DORNELES et al., 2012; PINHEIRO et al., 2013; MORAES et al., 2015; NEGRI FILHO et al., 2016; ARAÚJO et al., 2017; SBIZERA et al., 2017). Serological tests consist mainly of agar gel immunodiffusion (AGID) and competitive enzyme immunoassay (ELISAc). Despite the high occurrence in some Brazilian regions, there are few reports of clinical cases, which indicates that the virus is spread silently by the Brazilian herds (NOGUEIRA et al., 2009).

The occurrence of BT in Brazil is most likely associated to climatic conditions, because most of the Brazilian territory has high temperatures and humidity levels, conditions that favor the multiplication and maintence of the haematophagous vectors (COSTA et al., 2006; LOBATO et al., 2015).

\section{LITERATURE REVIEW}

BT is an infectious and non-contagious disease caused by the BTV. This virus is a member of the Orbivirus genus and is transmitted to domestic and wild ruminants (NOAMAN; ARZANI, 2016), especially sheep, the most susceptible species.
BT was first recorded at the end of the $19^{\text {th }}$ and early $20^{\text {th }}$ centuries, although farmers in South Africa recognized the disease since the introduction of European's sheep breeds, in the $18^{\text {th }}$ century. BT was first referred to as 'malaria catarrhal fever' and 'epizootic catarrh of sheep' by researchers in South Africa (MACLACHLAN, 2004).

The 'bluetongue' name is derived from the African word 'blauwtong', used by african farmers to describe the cyanotic tongue of some severely affected sheep (MACLACHLAN, 2004). DU TOIT (1944) confirmed that Culicoides spp. are the biological vectors of the BTV, when demonstrated that Culicoides imicola had been fed on the BTV infected sheep, and could transmit the disease to healthy sheep after an incubation period of several days in the insects.

BT was thought to be confined to the African continent. In 1943, however, the first well-documented epidemic of BT outside Africa occurred in sheep in Cyprus, an island country located in the Mediterranean (MACLACHLAN, 2004).

The disease was recognised in Israel (1949), and in the US States of Texas and California soon thereafter (1952). In Europe, a large endemic broke out on the Iberian Peninsula in Portugal (1956) and Spain (1957), where 179 thousand sheep died. Subsequently, the BT was recognised in the Middle East: with reports in Pakistan (1959), and India (1963). In 1977, it first appeared in Australia (MACLACHLAN, 2004). In 1998, the BT caused the death of more than one million sheep in Europe (PURSE et al., 2005). The identification in America, Asia and Europe confirmed that BT is an emerging disease and could devastate herds in the various regions of the globe. For this reason, the World Organisation for Animal Health (OIE) has classified BT as a compulsory disease (ACEVEDO et al., 2016).

With the recent spread of the disease to previously unaffected regions of Northern Europe, and the incursion of several additional serotypes into the US Southeastern regions and Northern Australia, BT has risen again, in proeminence, as one of the most significant livestock diseases of the $21^{\text {st }}$ century (COETZEE et al., 2012).

In South America, the first descriptions of BTV infection were reported by SILVA (1978), in Brazil, who described antibodies against the BTV in sheep and cattle from the state of São Paulo. In 1980, the BTV was isolated in the USA in 8 out of 60 bulls coming from Brazil, that were kept in quarantine (GROOCOCK; CAMPBELL, 1982). Since then, there is serological evidence for the presence of the BTV in Peru, Argentina, Brazil, Ecuador, Chile, and Colombia (CLAVIJO et al., 2002).

Thus, it is evident that the BTV is reported in tropical and subtropical regions all over the world, also present in many temperate regions, of latitudes between $40^{\circ} \mathrm{N}$ and $35^{\circ} \mathrm{S}$ (COETZEE et al., 2012), except in Antarctica (NOAMAN; ARZANI, 2016). 
In Brazil, an outbreak was first reported in the country and South America (LAGER, 2004) in 2001, in the state of Paraná, involving 130 sheep, 4 goats, and 70 seroreagent cattle, of which eight sheep and one goat presented clinical signs of the disease. In 2002, three outbreaks of the disease were also detected in Paraná, one involving goats, and the other two involving goats and sheep (LAGER, 2004). Since then, several serological studies on the various ruminant species show that the BTV is spreading throughout the country (Table 1), in 11 Brazilian states.

Economic loss is directly associated with the disease, due to high morbidity and mortality rates, and to indirect loss, caused by commercial restrictions on ruminants and their by-products, by vaccination vector control and treatment of clinically affected animals. Because of such loss, costs associated with BT exceed approximately U\$3 billion per year worldwide (COETZEE et al., 2012).

In Brazil, BALARO et al. (2014b) studied the costs of an outbreak of the BTV in sheep, in 2013, in the state of Rio de Janeiro, and over a six-month period U\$6.700 were spent directly and indirectly to treat the disease.

BTV belongs to the genus Orbivirus in the family Reoviridae, and, until today, 27 serotypes are identified worldwide (JENCKEL et al., 2015). Morphologically, this is a non-enveloped virus with an icosahedral organisation, its viral genome consists of 10 double stranded RNA segments encoding for non-structural proteins (NS1 - NS4), and seven structural proteins (VP1 - VP7) (ROY, 2008).

The outer layer consists mainly of two viral proteins (VP): VP2, and VP5. VP2 determines the serotype and is responsible for receptor binding, haemagglutination, and stimulation of host-specific immunity. VP5 interacts with the host cell membrane and demonstrated a lower humoral response. The middle layer is formed by VP7, which is the main determinant of serotype especificity and also provides na epitope in tests, such as ELISAc for detecting antibodies against the BTV, in addition to mediating surface fixation, penetration, and infection of insect cells (ROY, 2008). The innermost layer consists of

Table 1. Number of seropositive animals for bluetongue virus detected in Brazil, from 2000 to 2017, according to author, year, Brazilian state, test used, and animal species.

\begin{tabular}{|c|c|c|c|c|c|}
\hline Author & Year & State & Test $^{1}$ & Specie & (\%) seropositive/sampling \\
\hline MELO et al. & 2000 & PB & AGID & Bovine & $4.38(6 / 137)$ \\
\hline COSTA et al. & 2001 & RJ & AGID & Bovine & $62.02(169 / 282)$ \\
\hline KONRAD et al. & 2003 & MG & AGID & Bovine & $59.51(776 / 1304)$ \\
\hline COSTA et al. & 2006 & RS & AGID & Bovine & $0.60(8 / 1272)$ \\
\hline COSTA et al. & 2006 & RS & AGID & Ovine & $0.16(2 / 1331)$ \\
\hline ALVES et al. & 2009 & PB & AGID & Ovine & $8.40(43 / 506)$ \\
\hline NOGUEIRA et al. & 2009 & SP & AGID & Ovine & $65(651 / 1002)$ \\
\hline NOGUEIRA et al. & 2009 & $\mathrm{SP}$ & ELISAC & Ovine & $74.10(742 / 1002)$ \\
\hline TOMICH et al. & 2009 & MS & AGID & Bovine & $42(92 / 219)$ \\
\hline TOMICH et al. & 2009 & MS & AGIDE & Ovine & $10.90(6 / 55)$ \\
\hline TOMICH et al. & 2009 & MS & AGID & Deer & $0(49)$ \\
\hline SOUZA et al. & 2010 & BA & AGID & Ovine & $0.43(2 / 469)$ \\
\hline MOTA et al. & 2011 & PB & AGID & Ovine & $4.30(2 / 40)$ \\
\hline MOTA et al. & 2011 & PB & AGID & Goat & $3.90(2 / 41)$ \\
\hline DORNELES et al. & 2012 & DF & AGID & Ovine & $52.37(389 / 606)$ \\
\hline PINHEIRO et al. & 2013 & CE & AGID & Ovine & $27.30(74 / 271)$ \\
\hline BALARO et al. & $2014 a$ & RJ & AGID & Ovine & $81.40(79 / 97)$ \\
\hline MORAES et al. & 2015 & $\mathrm{SC}$ & AGID & Deer & $3.10(1 / 32)$ \\
\hline LIMA et al. & 2016 & MG & AGID & Sheep (outbreak) & $64.28(9 / 14)$ \\
\hline MATOS et al. & $2016 a$ & RJ & AGID & Sheep (outbreak) & $80(86 / 107)$ \\
\hline NEGRI FILHO et al. & 2016 & PR & ELISAC & Bovine & $100(633 / 633)$ \\
\hline NEGRI FILHO et al. & 2016 & PR & VN & Bovine & $64.61(409 / 633)$ \\
\hline ARAÚJO et al. & 2017 & PR & AGID & Bovine & $34.30(224 / 653)$ \\
\hline SBIZERA et al. & 2017 & $\mathrm{PR}\left(\mathrm{SC}^{2}\right)$ & AGID & Ovine & $31.19(34 / 109)$ \\
\hline
\end{tabular}


the proteins VP3, VP1, VP4, and VP6, involved in the transcription and replication of viral RNA (RAO et al., 2017).

Due to the nature of the segmented genomes the virus may suffer resorption of its segments when there is a concomitante infection by two strains of the same virus. In these cases, the newly replicated genomic segments are irregularly redistributed into the viral progeny, resulting in virions containing a mixture of segments of the two parental viruses. From an evolutionary point of view, resorption results in a very rapid genetic and phenotypic alteration (FLORES, 2007).

Serotypes present antigenic variations and the interaction between each serotype, and the host is not totally clear, since cross-reactions with other orbiviruses in the serological AGID test are observed (COSTA et al., 2006), probably due to the low specificity of the test.

In Brazil, the first virus isolation involved serotype 4, in the cattle exported to the USA, in 1980. In the outbreak of 2001, CLAVIJO et al. (2002) isolated serotype 12 from sheep and goats in the state of Paraná. Subsequently, several studies were carried out to identify the serotype involved in outbreaks in Brazil. In 2009, ANTONIASSI et al. (2010) isolated serotype 12 in sheep in the state of Rio Grande do Sul. BALARO et al. (2014a) isolated serotype 4 in sheep in the state of Rio de Janeiro. In 2014, serotype 17 was identified in Rio Grande do Sul (MATOS et al., 2016b). In 2015 and 2016, serotypes $3,14,18,19$, and 22 were isolated after the deaths of Bororos deer in an ecological reserve in the city of Foz do Iguaçú, state of Paraná (OIE, 2016). LIMA et al. (2016) detected serotype 4 in sheep from the state of Minas Gerais.

The virus is inactivated at $50^{\circ} \mathrm{C}$ for 3 hours, $60^{\circ} \mathrm{C}$ for 15 minutes, at a $\mathrm{pH}$ lesser than 6 , or higher than 8 , and in the presence of common disinfectants, such as phenolic and iodophors agents. However, the virus can remain ineffective for years in blood stored at $-20^{\circ} \mathrm{C}$ (OIE, 2013).

The BTV can naturally infect domestic ruminants, such as cattle, sheep, goats and buffaloes, and wild ruminants, including cervids and camelids (COETZEE et al., 2012). Nonetheless, the clinical disease is more common in sheep and deer. Vectors are fundamental for the maintenance and transmission of the BTV, considering that the infection is non-contagious (MACLACHLAN, 2004).

The BTV is primarily transmited by a hematophagous insect of the genus Culicoides, and 1.400 species have been already been globally described, of which $96 \%$ are obligatorily fed on mammals and birds worldwide, from the sea level up to an altitude of four thousand meters (TRINDADE et al., 2010). In Brazil, these midges are called "maruim", "mosquito-pólvora", or "mosquitos-do-mangue" (BANDEIRA et al., 2017).

The distribution of the species is associated with local environmental conditions, such as temperature, humidity, wind speed, and precipitation, and these midges require semiaquatic environments, such as manure, mud, wet and organic soil substrates for egg laying and larva development (PURSE et al., 2015; BANDEIRA et al., 2017). In this way, the transmission of the disease occurs in several regions: intensive and extensive agricutural environments, forests and woodlands, and periurban areas (PURSE et al., 2015).

Only females are haematophagous and are infected by ingesting blood from the infected host. The virus crosses the intestinal wall, replicates and spreads through the tissues and salivary glands, where viral replication continues. After the virus replicates itself in the salivar glands, transmission may occur. The period as from the infection to transmission varies from 10 to 15 days, and, once infected, vectors will remain lifelong (MELLOR, 2000).

The Culicoides spp. are more active at sunrise and sunset. However, climatic factors, such as temperature, wind, and rainfall can affect adult survival and activity (PURSE et al., 2015). The average life span of these vectors is three months, adults usually live from 10 to 20 days, and can survive for a maximum of 90 days in colder regions (MELLOR, 2000).

Culicoides are between 1 and $3 \mathrm{~mm}$, and, because of their size, they can disperse on flights, ranging from a short distance, with less than five kilometers, to windy movements, reaching hundreds of kilometers (PURSE et al., 2015).

Another important epidemiological factor in the BTV transmission is the possible preference of some species of Culicoides for a specific host, because several species preferentially feed on cattle (TOMICH et al., 2009).

Culicoides spp. are also responsible for the transmission to ruminants of other viruses of importance in veterinary medicine, such as the epizootic hemorrhagic disease (EHD) in deer, and the Schmallenberg virus (SBV) (PURSE et al., 2015).

The species of Culicoides that transmit the BTV in various regions around the world are very different (MACLACHLAN, 2004); Culicoides sonorensis is identified in North America; Culicoides imicola, in Africa and Southern Europe; Culicoides fulvus and Culicoides brevitarsis in Australia; Culicoides pusillus and Culicoides insignis in Southern USA, Central and South America; Culicoides obsoletus, and probably Culicoides pulicaris, were recently implicated as potential vectors in Northern Europe (LAGER, 2004; CARVALHO; SILVA, 2014).

According to BANDEIRA et al. (2017) there are more than 100 species of Culicoides known in Brazil, but information on the abundance and distribution of these insects is still limited. CARVALHO; SILVA (2014) demonstrated Culicoides insignis as the most abundant specie in the country's Northeastern region. In 2013, in Rio de Janeiro, MATOS et al. (2016a) identified, mainly, Culicoides pusillus and Culicoides insignis.

Based on vector distribution and environmental climatical conditions, LOBATO et al. (2015) classified the BT into four zones: endemic zones, located in regions of tropical climates, where Culicoides spp. and the virus are present during the entire year, without the occurence of the disease, but with possible infection; epidemic zones, where there is the presence of the vector during hot seasons, the infection 
and/or disease in these areas is focal, and the clinical disease can occur in the form of outbreaks, when climatic conditions allow the dissemination of biting midges; incursion zones, where the disease appears sporadically, usually when infected Culicoides are transported to these areas through the wind or due to climatic changes; free zones, correspond to the territory where the disease has never been reported, and the possibility of occurence is remote, because the temperate climate prevents the vector from circulating on the environment.

Considering the great survival conditions for Culicoides and the distribution of the BTV in the world, we can conclude that the Brazilian territory can host the BT disease in all its extension (LOBATO et al., 2015).

Although Culicoides are the main transmitters of BT, other forms of transmission are documented. In sheep and cattle, transmissions through semen has been reported; however, the infection only occurs when the animal is viremic and the semen is probably associated with traces of blood infected with the virus from the genital tract (KIRSCHVINK et al., 2009).

Placental transmission has already been reported in cattle, sheep and dogs. SAEGERMAN et al. (2011) studied 476 sheep and 26 aborted fetuses for seven months, and they concluded that transplacental infection occurs in animals naturally infected with the BTV serotype 8. Congenital infection has also been reported in countries such as the USA and South Africa, and it was associated to the use of modified live vacines involving serotypes $10,11,13$, and 17 , causing abortion, congenital abnormalities, and the birth of viremic animals (ANTONIASSI et al., 2010).

Serological evidence indicates that lions, cheetahs, wild dogs, jackals, and hyenas have antibodies to the BTV, which is suggestive of infection by feeding from a carcass of infected ruminants. There is no evidence that these animals are important to the natural cycle of the disease yet. (MACLACHLAN et al., 2009). WILBUR et al. (1994) reported the contamination of a vaccine with the BTV, causing the abortion of pregnant dogs and even death. DUBOVI et al. (2013) reported two cases of abortion in female dogs with a probable Culicoiderelated infection. This fact suggests that dogs may possibly act as host for BT.

Authors show that is possible for the BTV to be transmitted by the direct contact between infected animals (BATTEN et al., 2014), and in an experimental study other authors suggested that the reuse of contaminated needles can transmit the BTV (DARPEL et al., 2016).

It is important to emphasize that some factors influence the severity of the infection, such as: nutritional and immune status, stress, high temperatures (MACLACHLAN, 2004), sheep's age, and breed. In Brazil, for example, some sheep breeds proved to be more susceptible to the BTV, such as Lacaune, Texel, Hampshire Down, Corriedale, and Santa Inês (LOBATO et al., 2015), as well as Merino and Poll Dorset breeds in Europe (MACLACHLAN et al., 2009).
After haematophage performed by a infected midge, the virus is transported by the host dendritic cells from the skin to the local lymph nodes, and then, it spreads to the blood circulation, inducing a primary viremia. Initially, the virus is associated to all blood elements and it becomes associated exclusively to erythocytes (MACLACHLAN et al., 2009).

Pathogenesis is characterized by damage to small endotelial cells, resulting in tissue infarctation. The vasoactive mediators induced by viral replication worsen the endothelium and interfere with the function, thus allowing for increased vascular permeability, which leads to the development of edema, vascular thrombosis, tissue infarctation, necrosis, and hemorrhage (COETZEE et al., 2012).

The pathogenesis of the infection is similar in all ruminants; however, the severity of the disease is variable in these species, and cattle and goats are more resistant to the clinical disease. MACLACHLAN (2004), seeking to explain this clinical diversity among species, infected the pulmonary microvascular endothelial cells of sheep and cattle, and observed that there was more endothelial activation in bovine, with the increased transcription of genes encoding a variety of vasoactive and inflammatory mediators, and increase expression in cell surface adhesion molecules. In sheep, minimal activation of endothelial cells occured suggesting that there are differences in the immune response and interactions of the virus with the surface of red blood cells between species.

The BTV viremia in sheep has an average from 14 to 54 days; in goats, from 19 to 54 days; and in cattle, from 60 to 100 days. Despite this, there is no evidence of truly persistent BTV infection in domestic ruminants (MACLACHLAN et al., 2009).

Ruminants infected with the BTV develop a fast and high antibody response to a variety of viral proteins. Serotype specific neutralizing antibodies are directed against VP2 and can be detected by the serum neutralizing test. Antibodies directed against VP7, and other structural and non-structural proteins can be detected with serotype reactive assays, such as: AGID, and ELISAc (MACLACHLAN et al., 2009).

After the virus is inoculated into the ruminants by biting midge there will be viral replication and the BTV appears in bloodstream (MACLACHLAN et al., 2009). The clinical signs are highly variable even in susceptible species, such as sheep, reflecting inherent differences in the susceptibility of different sheep breeds (ACEVEDO et al., 2016).

In sheep, viremia peak lasts approximately seven days and is accompanied by fever $\left(39.5-40.8^{\circ} \mathrm{C}\right)$. Several clinical signs have been observed in outbreaks: depression, apathy and prostration; tachypnea; hyperemia and congestion of oral and nasal mucosa; serous nasal discharge, which may become mucopurulent and form crusts; lacrimation; excessive salivation; submandibular oedema and oeoedema of the lips, face, tongue, and eyelid; petechiae in the oral and conjuctive mucosa; hemorrhages and erosions of the lips; erosions, and 
oral ulcers (CLAVIJO et al., 2002; DARPEL et al., 2007; MACLACHLAN et al., 2009).

In addition to edema, the tongue may become cyanotic and protude out of the mouth, generating problems in swallowing and episodes of regurgitation (ANTONIASSI et al., 2010). This can cause anorexia, weight loss, and weakness to the animal that generates ruminal stasis. In some cases, hemorrhagic diarrhea is observed. Pulmonay edema can lead to dyspnea and death due to secondary pneumonia. Damage to hooves, such as hyperemia, and petechiae of the coronary bands can be observed, mainly in posterior limbs. The animal may be reluctant to move, and various degrees of lameness are observed (DARPEL et al., 2007). Falling wool and dermatites may also occur (MACLACHLAN et al., 2009).

Inflammation and petechial haemorrhage of the scrotum, epididymis inflammation, testicular degeneration, and alteration in semen may occur (KIRSCHVINK et al., 2009). There may also occur abortion, fetal mummification, lamb birth of weak, or congenitally defective animals, and severe impairment of the central nervous system (SAEGERMAN et al., 2011).

Most animals with acute infectation die 14 days after the onset of clinical signs, and mortality among susceptible sheep ranges from 2 to $30 \%$. Animals that recover from the disease normally demonstrate a prolonged recovery period, during which they can show loss of and reduction in fertility, milk production, and quality of wool (COETZEE et al., 2012).

Despite the high levels of the BTV in blood, the infection is usually asymptomatic in cattle, goats and wild ruminants, and these species are considered hosts for the BTV due to proctated viremia.

Goats are also considered resistant to the disease and present mild clinical signs. Facial and tongue oedema, nasal discharge, wounds and crusts on the snout and lips, and erythema of the udder have been reported (DERCKSEN et al., 2007).

Pathological findings include decreased globular volume and leucopenia, which progresses to neutrophilic leukocytosis and possible lymphopenia.

Skeletal myopathy, caused by the clinical disease, is reflected in increased levels of creatine phosphokinase (CPK) and aspartate aminotransferase (AST) (ANTONIASSI et al., 2010). ANTONIASSI et al. (2010) and BALARO et al. (2014a) noted the presence of disseminated intravascular coagulation (DIC) in disease outbreaks in sheep.

Necropsy findings reveal hyperemia, hemorrhage, erosion, and ulceration of the mucosa of the upper gastrointestinal tract and nasal cavity. The presence of petechiae, ecchymosis, or hemorrhage in the pulmonary artery was observed in several cases of the disease (BALARO et al., 2014a; LIMA et al., 2016), as well as necrosis of the heart muscle (MACLACHLAN et al., 2009). It is also possible to observe edema and hemorrhage in lymph nodes; hemorrhage in subcutaneous tissue; pulmonary edema with abundant foam in trachea; pleural and/or pericardial effusion; facial oedema, submandibular and abdominal wall muscle oedema (MACLACHLAN et al., 2009; KATSOULOS et al., 2016).

In Brazil, BT is part of the list of notifiable vesicular diseases, according to normative instruction No. 50 of the Ministry of Agriculture, Livestock and Food Supply (MAPA) (BRASIL, 2013).

Early clinical diagnosis leads to a fast implementation of control measures. However, no clinical signs are pathognomonic, and any disease that causes hemorrhage or edema can be mistaken for BTV.

The severity of clinical signs may vary considerably and may be influenced by individual and species variations, such as age, serotype differences, host immune status, climatic condition, and property management (MACLACHLAN, 2004).

The definitive diagnosis of BT can only be confirmed with a laboratory analysis, by virus isolation through inoculation in sheep, embryonated eggs, or cell cultures; by identification of the agent, through virus-neutralization $(\mathrm{VN})$; or by the detection of specific antibodies, using the ELISAc, agar gel immunodifusion (AGID) and complement fixation (CF) tests. Molecular biology techniques can also be used by the RT-PCR method (CLAVIJO et al., 2002; LAGER, 2004; OIE, 2018).

Among viral isolation tests, the most sensitive method is the inoculation in embryonated chicken eggs (OIE, 2018). Among serological tests, the most commonly used are ELISAc and AGID (SOUZA et al., 2010). Antibodies appear from five to fifteen days after infection; however, they do not persist for the animal's entire life (MACLACHLAN, 2004), being a persistent virus only in vectors (MACLACHLAN et al., 2009). Thus, positive serological results only confirm that the animal was previously infected with the BTV (MACLACHLAN, 2004).

AGID, a simple and economical test, is one of the standart tests recommended by the OIE for certifying animals for international ruminant transit, since 1982. This test detects antibodies to VP7, but one of its disadvantages is the possibility of cross-reacting against other Orbiviruses, such as the EHD (OIE, 2018). Unfortunately, AGID can only determine positive or negative animals, and it does not identify the serotypes present (COSTA et al., 2006), thus being a test of low specificity (OIE, 2018) and sensitivity (WARD; THURMOND, 1995).

ELISAc was developed to detect BTV-specific antibodies, focused on the VP7 protein, without detecting cross-reactive antibodies against other Orbiviruses (OIE, 2018). This is a fast method, that allows defining the serum or plasma antibody at the beggining of the $6^{\text {th }}$ day after infection (KOUMBATI et al., 1999). Several studies have demonstrated differences between serum prevalences detected by AGID and ELISAc worldwide, in distinct species (REDDINGTON et al., 1991; KOUMBATI et al., 1999; SHRINGI; SHRINGI, 2005; NOGUEIRA et al., 2009), and show that, compared to other serological tests, ELISAc shows high sensivity and specificity for BT (NOAMAN; ARZANI, 2016; OIE, 2018). 
The reverse transcription polymerase chain reaction quantitative in real time (RT-PCR) has been widely used to diagnose the BTV, because it allows identifying the serotype and detects the BTV's RNA in samples up to six months after infection (ANTHONY et al., 2007).

Other diagnosis methods are avaible, including the immunofluorescence test, immunospot testing, indirect peroxidase and anti peroxidase identifcation, or serotyping with the virus seroneutralization, microtiter neutralization, and fluorescence inhibition test. They are nonetheless rarely used (OIE, 2018).

In small ruminants, various diseases can be mistaken for BT, such as: foot-and-mouth-disease; contagious ecthyma; vesicular stomatitis; peste des petits ruminants; sheep pox; pneumonia; hepatogenic photosensitization caused by plant intoxication and mycotoxins; Rift Valley fever; parasitic gastroenteritis; salmonellosis; infectious pustular dermatites; pododermatitis; ulcerative dermatites; polyarthritis; white muscle disease associated to selenium and vitamin E deficiency; and EHD (WILLIAMSON et al., 2008).

There is no specific therapy for BT, and a symptomatic treatment must be performed. ANTONIASSI et al. (2010) reported the recovery of sheep after sodium dipyrone, penicilina and dexamethasone acetate administration, whereas BALARO et al. (2014a) reported an improvement in clinical signs of sheep after streptomycin with penicilina administration.

Imports of countries with BT infections should be immediatly banned as a priority measure, followed by monitoring farms that breed domestic ruminants, with clinical examination and serological tests (SPERLOVA; ZENDULKOVA, 2011).

The omnipresent distribution of biting midges, unvaccinated wild, and domestic ruminants makes it impossible to eradicate the BTV. Thus, control becomes an important measure to limit the economic impacts of such disease (COETZEE et al., 2012).

Some procedures that limit the exposure of animals to Culicoides bites include avoiding contact with low-humid pasture, stabling animals between dusk and down, and using insect repellents on animals (COETZEE et al., 2012).

Although cattle are considered hosts for the BTV, due to prolonged viremia, concomitante grazing with sheep is suggested considering the Culicoides preference for cattle (TOMICH et al., 2009).

Vector control is a challenge, and the use of insecticides can be applied on hosts on air and aquatic environments (PINHEIRO et al., 2007), and several management methods have been employed, such as dichlorodiphenyl-trichloroethane (DDT), widely used for malaria vector control (Anopheles sp.) (BANDEIRA et al., 2017). Organoclorines and organophosphorous compounds are prohibited due to their high toxicity. Other substances are also used, such as pyrethroids, but have not proved to be effective (BANDEIRA et al., 2017). However, these measures have often proved to be inefficient, as well as causes of environmental problems, due to contamination and financial expenses (PINHEIRO et al., 2007).

Many countries use vaccines as preventive measures in sheep. Inactivated and live attenuated vacines are currently avaible. A dose of attenuated vaccine is enough to provide good protection for at least one year. However, there are concerns about the use of these vaccines, because they can cross placenta and infect fetuses. Inactivated vaccines cause little or no side effects, however, induce a slower immune response than attenuated vaccine, and require anual revaccination (MACLACHLAN; MAYO, 2013). Due to the high variety of serotypes (27) (JENCKEL et al., 2015), the choice for an effective vaccine should occur according to the predominant serotype in a given region. Currently, there is no vaccine against the BTV available in Brazil, mainly because of the lack of all serotypes in the country and in Brazilian regions.

\section{CONCLUSION}

Bluetongue is widespread worldwide and it probably persists because of the hot and humid climate, that promotes the proliferation of Culicoides spp. Measures that reduce the risk factors and are associated to the infection by the BTV must be adopted.

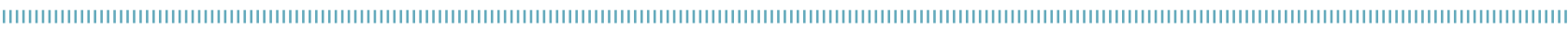
REFERENCES

ACEVEDO, A.M.; HINOJOSA, Y.; RELOVA, D.; PERERA, C.L. Bluetongue virus: a know virus, a current threat. Revista de Salud Animal, San José de las Lajas, v.38, n.1, p.52-59, 2016.

ALVES, F.A.L.; ALVES, C.J.; AZEVEDO, S.S.; SILVA, W.W.; SILVA M.L.C.R.; LOBATO, Z.I.P.; CLEMENTINO, I.J. Soroprevalência e fatores de risco para a língua azul em carneiros das mesorregiões do Sertão e da Borborema, semi-árido do Estado da Paraíba, Brasil. Ciência Rural, Santa Maria, v.39, n.2, p.484-489, 2009. http://dx.doi.org/10.1590/ So $103-84782008005000066$
ANTHONY, S.; JONES, H.; DARPEL, K.E.; ELLIOT, H.; MAAN, S.; SAMUEL, A.; MELLOR, P.S.; MERTENS, P.P.C. A duplex RT-PCR assay for detection of genome segment 7 (VP7 gene) from 24 BTV serotypes. Journal of Virological Methods, Foster City, v.141, n.2, p.188-197, 2007. http://dx.doi.org/10.1016/j.jviromet.2006.12.013

ANTONIASSI, N.A.B.; PAVARINI, S.P.; RIBEIRO, L.A.O.; SILVA, M.S.; FLORES, E.F;:DRIEMEIER, D. Alterações clínicas e patológicas em ovinos infectados naturalmente pelo vírus da língua azul no Rio Grande do Sul. Pesquisa Veterinária Brasileira, Rio de Janeiro, v.30, n.12, p.1010-1016, 2010. http://dx.doi.org/10.1590/SO100-736X2010001200002 
ARAÚJO, C.M.F.; PINTO, D.N.A.; NEGRI FILHO, L.C.; SILVA, D.A. VERONEZ, J.V.; VIEIRA, M.V.; SILVA, C.B.; SANTOS, M.M.; SILVA, L.C.; OKANO, W. Detecção de anticorpos anti-bluetongue virus (BTV) em bacia leiteira paranaense. Revista Acadêmica: Ciência Animal, Curitiba, v.15, supl.2, p.419-420, 2017. http://dx.doi. org/10.7213/academica.15.S02.2017.209

BALARO, M.F.A.; LIMA, M.S.; FAVA, C.D.; OLIVEIRA, G.R.; PITUCO, E.M.; BRANDÃO, F.Z. Outbreak of Bluetongue virus serotype 4 in dairy sheep in Rio de Janeiro, Brazil. Journal of Veterinary Diagnostic Investigation, Kansas City, v.26, n.4, p.567-570, 2014a. https://doi. org/10.1177/1040638714538020

BALARO, M.F.A.; OLIVEIRA, G.R.; BRANDÃO F.Z.; VALENTE, L.C.M. Treatment costs and some direct costs of bluetongue outbreak in a dairy sheep farm in Rio de Janeiro, Brazil, South America. In: WORLD BUIATRICS CONGRESS, 28., Cairns, Australia: International Veterinary Information Service, 2014b. p.241247.

BANDEIRA, M.C.A.; BRITO, G.A.; PENHA, A., SANTOS, C.L.C.; REBÊLO, J.M.M. The influence of environmental management and animal shelters in vector control of Culicoides (Diptera, Ceratopogonidae) in northeastern Brazil. Journal of Vector Ecology, Washington, v.42, n.1, p.113-119, 2017. https://doi. org/10.1111/jvec. 12245

BATTEN, C.; DARPEL, K.; HENSTOCK, M.; FAY, P.; VERONESI, E.; GUBBINS, S.; GRAVES, S.; FROST, L.; OURA, C. Evidence for transmission of bluetongue virus serotype 26 through direct contact. PLoS One, San Francisco, v.9, n.5, p.e96049, 2014. https://doi.org/10.1371/journal.pone.0096049

BRASIL. Ministério de Agricultura Pecuária e Abastecimento. Instrução Normativa $n^{\circ}$ 50, de 24 de setembro de 2013. Doenças de notificação obrigatória ao serviço veterinário oficial. Diário Oficial da União, Brasília, Seção 1, p.47. Avaliable from: <www.agricultura.gov.br>. Access on: Sept. 202017.

CARVALHO, L.P.C.; SILVA, F.S. Seasonal abundance of livestockassociated Culicoides species in northeastern Brazil. Medical and Veterinary Entomology, Washington, v.28, n.2, p.228-231, 2014. https://doi.org/10.1111/mve.12043

CLAVIJO, A.; SEPULVEDA, L.; RIVA, J.; PESSOA-SILVA, M.; TAILOR-RUTHES, A.; LOPEZ, J.W. Isolation of bluetongue virus serotype 12 from na outbreak of the disease in South America. Veterinary Record, London, v.151, p.301-302, 2002. http:// dx.doi.org/10.1136/vr.151.10.301

COETZEE, P.; STOKSTAD, M.; VENTER, E.H.; MYRMEL, M.; VAN VURUREN, M. Bluetongue: a historical and epidemiological perspective with the emphasis on South Africa. Virology Journal, London, v.9, n.2, p.198, 2012. http://dx.doi. org/10.1186/1743-422X-9-198

COSTA, A.S.; FERREIRA, A.E.C.; FARIA JUNIOR, T.M.; BRITO, S.N.; ANDRADE, M.C. Diagnóstico do vírus da Língua Azul na População Bovina do Estado do Rio de Janeiro através do teste de Imunodifusão em Gel de Agar (IDGA). In: XI Jornada de Iniciação Científica da UFRRJ. Anais da XI Jornada de Iniciação Científica da UFRRJ. v. 11 , n. 2, p. 173-176, 2001.
COSTA, J.R.R.; LOBATO, Z.I.P.; HERRMANN, G.P.; LEITE, R.C.; HADDAD, J.P.A. Prevalência de anticorpos contra o vírus da língua azul em bovinos e ovinos do sudoeste e sudeste do Rio Grande do Sul. Arquivo Brasileiro de Medicina Veterinária e Zootecnia, Belo Horizonte, v.58, n.2, p.273-275, 2006. http://dx.doi. org/10.1590/SO102-09352006000200017

DARPEL, K.E.; BATTEN, C.A.; VERONESI, E.; SHAW, A.E.; ANTHONY, S.; BACHANEK-BANKOWSKA, K.; KGOSANA, L.; BIN-TARIF, A.; CARPENTER, S.; MULLER-DOBLIES, U.U.; TAKAMATSU, H.H.; MELLOR, P.S.; MERTENS, P.P.C.; OURA, C.A.L. Clinical signs and pathology shown by British sheep and cattle infected with bluetongue virus serotype 8 derived from the 2006 outbreak in northern Europe. Veterinary Record, London, v.161, n.8, p.253261, 2007. http://dx.doi.org/10.1136/vr.161.8.253

DARPEL, K.E.; BARBER, J.; HOPE, A.; WILSON, A.J.; GUBBINS, S.; HENSTOCK, M.; FROST, L.; BATTEN, C.; VERONESI, E.; MOFFAT, K.; CARPENTER, S.; OURA, C.; MELLOR, P.S.; MERTENS, P.P.C. Using shared needles for subcutâneos inoculation can transmit bluetongue virus mechanically between ruminant hosts. Scientific Reports, New York, v.6, art.n.20627, 2016. http://dx.doi.org/10.1038/srep20627

DERCKSEN, D.; GROOT NIBBELINK, N.; PAAUWE, R.; BACKX, A.; VAN RIJN, P.; VELLEMA, P. First outbreak in goats in the Netherlands. Tijdschr Diergeneeskd, Netherlands, v.132, n.20, p.786-790, 2007.

DORNELES, E.M.S.; MORCATTI, F.C.; GUIMARÃES, A.S.; LOBATO, Z.I.P.; LAGE, A.P.; GONÇALVES, V.S.P.; GOUVEIA, A.M.G.; HEINEMANN, M.B. Prevalence of bluetongue virus antibodies in sheep from Distrito Federal, Brazil. Semina: Ciências Agrárias, Londrina, v.33, n.4, p.1521-1524, 2012. https://dx.doi. org/10.5433/1679-0359.2012v33n4p 1521

DUBOVI, E.J.; HAWKINS, M.; GRIFFIN JUNIOR, R.A.; JOHNSON, D.J.; OSTLUND, E.N. Isolation of Bluetongue virus from canine abortions. Brief Research Reports, Lansing, v.25, n.4, p.490-492, 2013. https://dx.doi.org/10.1177/1040638713489982

DU TOIT, R.M. The transmission of bluetongue and horsesickness by Culicoides. Onderstepoort. Journal of Veterinary Science and Animal Industy, Virginia, v.19, n.1-2, p.7-16, 1944.

FLORES, E.F. Virologia Veterinária. Santa Maria: Editora da UFSM, 2007. 888p.

GROOCOCK, C.M.; CAMPBELL, C.H. Isolation of an exotic serotype of bluetongue virus from imported cattle in quarantine. Canadian Journal of Comparative Medicine, Maryland, v.46, n.2, p.160-164, 1982.

JENCKEL, M.; BRÉAD, E.; SCHULZ, C.; SAILLEAU, C.; VIAROUGE, C.; HOFFMAN, B.; HOPER, D.; BEER, M.; ZIENTARA, S. Complete coding genome sequence of putative novel bluetongue virus serotype 27. Genome Announcements, New York, v.3, n.2, p.e000 16-15, 2015. https://doi.org/10.1 128/genomeA.00016-15

KATSOULOS, P.D.; GIADINIS, N.D.; CHAINTOUTIS, S.C.; DOVAS, C.I.; KIOSSIS, E.;TSOUSIS, G.; PSYCHAS, V.; VLEMMAS, I.; PAPADOPOULOS, T.; PAPADOPOULOS, O. ZIENTARA, S.; KARATZIAS, H.; BOSCOS, C. Epidemiological characteristics and clinicopathological features of bluetongue in sheep and cattle, during the 2014 BTV serotype 4 incursion in Greece. Tropical Animal Health Production, v.48, n.3, p.469-477, 2016. https://doi.org/10.1007/s1 1250-015-0974-5 
KIRSCHVINK, N.; RAES, M.; SAEGERMAN, C. Impact of a natural bluetongue serotype 8 infection on semen quality of Belgian rams in 2007. Journal Veterinary, London, v.182, n.2, p.244251, 2009. https://dx.doi.org/10.1016/j.tvjl.2008.06.008

KONRAD, P.A.; RODRIGUES, R.O.; CHAGAS, A.C.P.; PAZ, G.F.; LEITE, R.C. Anticorpos contra o vírus da língua azul em bovinos leiteiros de Minas Gerais e associações com problemas reprodutivos. Revista da Faculdade de Zootecnia, Veterinária e Agronomia, Uruguaiana, v.10, n.1, p.117-125. 2003.

KOUMBATI, M.; MANGANAB, O.; MELLORC, P.S.; PAPADOPOULOSA, $O$. Duration of bluetongue viraemia and serological responses in experimentally infected European breeds of sheep and goats. Veterinary Microbiology, London, v.64, n.4, p.277-285, 1999. https://dx.doi.org/10.1016/s0378-1135(98)00255-7

LAGER, I.A. Bluetongue virus in South America: Overview of viruses, vectors, surveillance and unique features. Veterinaria Italiana, Rome, v.40, n.3, p.89-93, 2004.

LIMA, P.A.; UTIUMI, K.U.; NAKAGAKI, K.Y.R.; BIIHRER, D.A.; ALBUQUERQUE, A.S.; SOUZA, F.R.; MATOS, A.C.D.; LOBATO, Z.I.P.; DRIEMEIER, D.; PECONICK, A.P.; VARASCHIN, M.S.; RAYMUNDO, D.L. Diagnoses of ovine infection by the serotype- 4 bluetongue virus on Minas Gerais, Brazil. Acta Scientiae Veterinariae, Porto Alegre, v.44, supl.1, p.01-05, 2016.

LOBATO, Z.I.P.; GUEDES, M.I.M.C.; MATOS, A.C.D. Bluetongue and others orbiviruses in South America: gaps and challenges. Veterinaria Italiana, Rome, v.51, n.4, p.253-262, 2015. https:// dx.doi.org/10.12834/Vetlt.600.2892.1

MACLACHLAN, N.J. Bluetongue: pathogenesis and duration of viraemia. Veterinaria Italiana, Rome, v.40, n.4, p.462-467, 2004.

MACLACHLAN, N.J.; DREW, C.P.; DARPEL, K.E.; WORWA, G. The pathology and pathogenesis of bluetongue. Journal of Comparative Pathology, London, v.141, n.1, p.1-16, 2009. https://doi. org/10.1016/j.jcpa.2009.04.003

MACLACHLAN, N.J.; MAYO, C.E. Potencial strategies for control of bluetongue, a globally emerging, Culicoides-transmitted viral disease of ruminant livestock and wildlife. Antiviral Research, London, v.99, n. 1, p.79-90, 2013. https://doi.org/10.1016/j. antiviral.2013.04.021

MATOS, A.C.D.; BALARO, M.F.A.; GUEDES, M.I.M.C.; COSTA, E.A.; ROSA, J.C.C.; COSTA, A.G.; BRANDÃO, F.Z.; LOBATO, Z.I.P. Epidemiology of a Bluetongue outbreak in a sheep flock in a Brazil. Veterinaria Italiana, Rome, v.52, n.3-4, p.325-331, 2016a. https://doi.org/10.12834/Vetlt.602.2901.2

MATOS, A.C.D.; ROSA, J.C.C.; NOMIKOU, K.; GUIMARÃES, L.L.B.; COSTA, E.A.; GUEDES, M.I.M.C.; DRIEMEIER, D.; LOBATO, Z.I.P.; MERTENS, P.P.C. Genome Sequence of Bluetongue virus Serotype 17 Isolated in Brazil in 2014. Genome Announcements, New York, v.4, n.5, p.e01 161-16, 2016b. https://doi.org/10.1128/ genomeA.01161-16

MELLOR, P.S. Replication of Arboviruses in Insect Vectors. Journal of Comparative Pathology, London, v. 123, n.4, p.231-247, 2000. https://doi.org/10.1053/jcpa.2000.0434
MELO, C.B.; OLIVEIRA, A.M.; AZEVEDO, E.O.; LOBATO, Z.I.P.; LEITE, R.C. Anticorpos contra o vírus da língua azul em bovinos do sertão da Paraíba. Arquivo Brasileiro de Medicina Veterinária e Zootecnia, Belo Horizonte, v.52, n.1, p.19-20, 2000. http:// dx.doi.org/10.1590/S0102-09352000000100004

MORAES, A.N.; FELIPPI, D.A.; BALDINI, M.H.M.; CUBAS, Z.S.; MORAES, W.; OLESKOVICZ, N.; LOBATO, Z.I.P.; ROSA, J.C.C. Soroprevalência de doença da língua azul e doença epizoótica hemorrágica de cervídeos do gênero Mazama na região serrana do estado de Santa Catarina - Brasil. In: SEMINÁRIO DE INICIAÇÃO CIENTÍFICA DA UDESC, 25., Florianópolis. Anais... Florianópolis: UDESC, 2015.

MOTA, I.O.; CASTRO, R.S.; ALENCAR, S.P.; LOBATO, Z.I.P.; LIMA FILHO, C.D.F.; ARAÚJO SILVA, T.L.; DUTRA, A.C.T.; NASCIMENTO, S.A. Anticorpos contra o vírus do grupo da língua azul em caprinos e ovinos do sertão de Pernambuco e inferência sobre sua epidemiologia em regiões semiáridas. Arquivo Brasileiro de Medicina Veterinária e Zootecnia, Belo Horizonte, v.63, n.6, p.1595-1598, 2011 . http://dx.doi.org/10.1590/ so102-09352011000600045

NEGRI FILHO, L.C.; NOGUEIRA, A.H.C.; STEFANO, E.; KATTO, S.; OKUDA, L.H.; SILVA, L.C.; PITUCO, E.M.; OKANO, W. Detecção de anticorpos contra o sorotipo 4 da língua azul (btv-4) em bovinos leiteiros da mesorregião norte central do Paraná, Brasil. Revista de Educação Continuada em Medicina Veterinária e Zootecnia do CRMV-SP, São Paulo, v. 14, n.2, 2016.

NOAMAN, V.; ARZANI, H. Environmental and host factors affecting seroprevalence of bluetongue virus infections of sheep. Comparative Clinical Pathology, London, v.26, n.2, p.397-403, 2016.

NOGUEIRA, A.H.C.; PITUCO, E.M.; STEFANO, E.; CURCI, V.C.L.M.; CARDOSA, T.C. Detecção de anticorpos contra o vírus da língua azul em ovinos na região de Araçatuba, São Paulo, Brasil. Ciência Animal Brasileira, Goiânia, v.10, n.4, p.1271-1276, 2009.

PINHEIRO, R.R.; ALVES, F.S.F.; ANDRIOLI, A. Enfermidades infecciosas de pequenos ruminantes: epidemiologia, impactos econômicos, prevenção e controle: uma revisão. Revista Brasileira de Higiene e Sanidade Animal, Fortaleza, v.01. n.01, p.44-66, 2007. http://dx.doi.org/10.5935/1981-2965.20070004

PINHEIRO, R.R.; SOUZA, T.S.; FEITOSA, A.L.V.L.; ARAGÃO, M.A.C.; LIMA, C.C.V.; COSTA, J.N.; ANDRIOLI, A.; TEIXEIRA, M.F.S.; BRITO, R.L.L. Frequencia de anticorpos contra o vírus da língua azul em ovinos do estado do Ceará, Brasil. Arquivos do Instituto Biológico, São Paulo, v.80, n. 1, p.35-42, 2013. http://dx.doi.org/10.1590/ S1808-16572013000100006

PURSE, B.V.; MELLOR, P.S.; ROGERS, D.J.; SAMUEL, A.R.; MERTENS, P.P.C; BAYLIS, M. Climate change and the recent emergence of bluetongue in Europe. Nature Reviews Microbiology, New York, v.3, n.2, p. $171-181$, 2005. https://doi.org/10.1038/nrmicro 1090

PURSE, B.V.; CARPENTER, S.; VENTER, G.J.; BELLIS, G.; MULLENS, B.A. Bionomics of temperate and tropical culicoides midges: knowledge gaps and consequences for transmission of culicoides-borne viruses. Annual Review of Entomology, Lafayette, v.60, n.20, p.373-392, 2015 . https://doi.org/10.1146/ annurev-ento-010814-020614 
RAO, P.P.; HEDGE, N.R.; SINGH, K.P.; PUTTY, K.; HEMADRI, D.; MAAN, N.S.; REDDY, Y.N.; MANN, S.; MERTENS, P.P.C. Bluetongue: aetiology, epidemiology, pathogenesis, diagnosis and control. In: BAYRY, J. Emerging and re-emerging infectious diseases of livestock. 1. ed. Cham, Switzerland: Springer International Publishing, 2017. 446p. https://doi.org/10.1007/978-3-319-47426-7

ROY, P. Functional mapping of bluetongue virus proteins and their interactions with host proteins during virus replication. Cell Biochemistry Biophysics, London, v.50, n.3, p. 143-157, 2008. https://doi.org/10.1007/s12013-008-9009-4

REDDINGTON, J.J.; REDDINGTON, G.M.; MACLACHLAN, N.J. Competitive ELISA for detection of antibodies to the group antigen of bluetongue virus. Journal of Veterinary Diagnostic Investigation, New York, v.3, n.2, p.144-147, 1991. https:// doi.org/10.1177/104063879100300207

SAEGERMAN, C.; BOLKAERTS, B.; BARICALLA, C.; RAES, M.; WIGGERS, L.; DE LEEUW, I.; VANDENBUSSCHE, F.; ZIMMER, J-Y.; HAUBRUGE, E.; CASSART, D.; DE CLERCQ, K.; KIRSCHVINK, The impact of naturally-occurring, trans-placental bluetongue virus serotype-8 infection on reproductive performance in sheep. The Veterinary Journal, London, v. 187, n. 1, p.72-80, 201 1. http:// dx.doi.org/10.1016/j.tvjl.2009.11.012 .

SBIZERA, M.C.R.; CUNHA FILHO, L.F.C.; BARRETO, J.V.P.; LOCOMAN, D.; SUDAK, M.M.; FINCO, M.V.; SOUZA, D.F.M. Ocorrência de anticorpos para o vírus da língua azul em ovinos da região CentroSul do Paraná. Revista Acadêmica: Ciência Animal, Curitiba, v.15, n.2, p.41-42, 2017. http://dx.doi.org/10.7213/cienciaanimal. v15iSuppl\%202.16869

SHRINGI, S.; SHRINGI, B.N. Comparative efficacy of standard AGID, CCIE, and competitive ELISA, for detecting bluetongue virus antibodies in indigenous breeds of sheep and goats in Rajasthan, India. Journal of Veterinary Science, Seoul, v.6, n.1, p.77-79, 2005.

SILVA, F.J.F. Relatório sobre estudos de ocorrência de Língua Azul em São Paulo: relatório da comissão de estudos. Portaria Ministerial, n.150, 1978. Brasília: Ministério da Agricultura, 1978.

SOUZA, T.S.; COSTA, J.N.; MARTINEZ, P.M.; COSTA NETO, A.O.; PINHEIRO, R.R. Anticorpos contra o vírus da língua azul em rebanhos ovinos da microrregião de Juazeiro, Bahia. Arquivos do Instituto Biológico, São Paulo, v.77, n.3, p.419-427, 2010.
SPERLOVA, A.; ZENDULKOVA, D. Bluetongue: a review. Veterinárni Medicína, Prague, v.56, n.9, p.430-452, 2011 . https://doi. org/10.17221/3206-VETMED

TOMICH, R.G.P.; NOGUEIRA, M.F.; LACERDA, A.C.R.; CAMPOS, F.S.; TOMAS, W.M.; HERRERA, H.M.; LIMA-BORGES, P.A.; PELLEGRIN, A.O.; LOBATO, Z.I.P.; SILVA, R.A.M.S.; PELLEGRIN, L.A.; BARBOSASTANCIOLI, E.F. Sorologia para o vírus da língua azul em bovinos de corte, ovinos e veados campeiros no Pantanal sul-matogrossense. Arquivo Brasileiro de Medicina Veterinária e Zootecnia, Belo Horizonte, v.61, n.5, p.1222-1226, 2009. http://dx.doi. org/10.1590/SO 102-09352009000500028

TRINDADE, R.L.; GORAYEB, I.S. Maruins (Diptera: Ceratopogonidae: Culicoides), após a estação chuvosa, na Reserva de Desenvolvimento Sustentável Itatupã-Baquiá, Gurupá, Pará, Brasil. Revista PanAmazônica de Saúde, Ananindeua, v.1, n.2, p.121-130, 2010. http://dx.doi.org/10.5123/S2 176-62232010000200015

WARD, M.P.; THURMOND, M.C. Climatic factors associated with risks of seroconversion of cattle to bluetongue viruses in Queensland. Preventive Veterinary Medicine, London, v.24, n.2, p.129-136, 1995. https://doi.org/10.1016/0167-5877(94)00458-U

WILBUR, L.A.; EVERMANN, J.F.; LEVINGS, R.L., STOLL, I.R., STARLING, D.E.; SPILLERS, C.A.; GUSTAFSON, G.A.; MCKEIRNAN, A.J. Abortion and death in pregnant bitches associated with a canine vaccine contaminated with bluetongue virus. Journal of the American Veterinary Medical Association, New York, v.204, n.1 1 1, p.1762-1765, 1994.

WILLIAMSON, S.; WOODGER, N.; DARPEL, K. Differential diagnosis of bluetongue in cattle and sheep. In Practice, Edinburgh, v.30, n.5, p.242-251, 2008. http://dx.doi.org/10.1136/inpract.30.5.242

WORLD ORGANISATION FOR ANIMAL HEALTH (OIE). Aetiology, epidemiology, diagnosis, prevention and control references. 2013. Available from: < http://www.oie.int/fileadmin/Home/eng/Animal_ Health_in_the_World/docs/pdf/Disease_cards/BLUETONGUE. pdf >. Access on: Jan. 092018.

WORLD ORGANISATION FOR ANIMAL HEALTH (OIE). Report archive. 2016. Available from: <http://www.oie.int/wahis_2/ public/wahid.php/Diseaseinformation/reportarchive>. Access on: Jan. 072018.

WORLD ORGANISATION FOR ANIMAL HEALTH (OIE). Manual of diagnostic tests and vaccines for terrestrial animals. 2018. Chapter 2.1.3. Bluetongue virus. Available from: <https://www. oie.int/fileadmin/Home/eng/Health_standards/tahm/3.01.03_ BLUETONGUE.pdf>. Access on: May 012019. 